Między wykluczeniem a dobrobytem. Refleksja nad społeczna myśla encykliki „Centesimus annus” Jana Pawła II, red. B. Bąk,

R. Kantor, M. Kluz, J. Młyński, Kraków 2017, s. 103-123.

DOI: http://dx.doi.org/10.15633/9788374386289.05

Ks. dr hab. Marek Kluz, prof. UPJPII

Wydział Teologiczny Sekcja w Tarnowie Uniwersytetu Papieskiego

Jana Pawła II w Krakowie

Ks. dr Józef Młyński

Uniwersytet Kardynała Stefana Wyszyńskiego w Warszawie

\title{
Współczesne zamachy na instytucję małżeńską
}

Instytucja małżeńska $\mathrm{z}$ natury i prawa jest związkiem nierozerwalnym. Dlatego wysiłek małżonków powinien się kierować ku odsunięciu tego wszystkiego, co mogłoby zagrozić owej wspólnocie i ją zniszczyć. Obserwując współczesną rzeczywistość, łatwo daje się zauważyć, że przemiany makro- i mikrospołeczne wymuszają zmiany w funkcjonowaniu małżeństwa. Jako instytucja tworzy ono wiele zależności między jednostką a społeczeństwem. W ten sposób ulega różnym, nie zawsze korzystnym przeobrażeniom. Niestety nic nie wskazuje na to, aby współczesnym małżeństwom żyło się coraz lepiej. Dość często związki te ulegają procesom sekularyzacji i liberalizacji. Prądy te coraz szybciej się rozwijają, a człowiek, nie uświadamiając sobie zła, jakie ze sobą niosą, brnie drogą donikąd.

Niewystarczalna troska państwa o małżeństwo stwarza trudną sytuację ekonomiczną, co prowadzi do wielu problemów w tej instytucji, 
niekoniecznie tylko ekonomicznych. Mąż i żona, pozostawieni samym sobie w pełnieniu przez nich ważnych funkcji w małżeństwie i rodzinie, nie tylko się gubią, lecz także przede wszystkim ulegają procesom alienacji. Następstwem takiego stanu mogą być - a może już są - groźne sygnały braku właściwego funkcjonowania małżeństw

Współczesne małżeństwo oparte na sakramentalnym związku kobiety i mężczyzny coraz częściej w świadomości ludzi traci religijny wymiar. Jak niegdyś z radością przyjmowano zmianę warunków, które pozwalały na zawarcie związku religijnego, by w ten sposób doświadczyć prawdziwej, normalnej, bogatszej w człowieczeństwo, wewnętrznie autonomicznej rodziny, tak dzisiaj opinia społeczna aprobuje małżeństwa bez związku sakramentalnego. Jak się wydaje, obecnie nie dziwi też już fakt wspólnego życia mężczyzny i kobiety z dziećmi bez jakiegokolwiek usankcjonowania. Modne stały się kohabitacja, szczególnie wśród młodych ludzi, oraz wolne związki. Podkreśla to wyraźnie Jan Paweł II w encyklice Centesimus annus:

Często się zdarza, że (...) człowiek skłania się do traktowania siebie samego i własnego życia raczej jako zespołu doznań, których należy doświadczyć, aniżeli dzieła, które ma wypełnić. Stąd się wywodzi brak wolności, a w konsekwencji rezygnacja $\mathrm{z}$ angażowania się w stały związek $\mathrm{z}$ inną osobą ${ }^{1}$.

Tymczasem małżeństwo powinno być instytucją świętą i nierozerwalną, podstawą jedności, miłości i wierności. Niestety współczesne trendy są zgoła odmienne. W myśli ogólnospołecznej małżeństwo jest instytucją rozerwalną i naruszalną, bo można je rozwiązać, nawet $\mathrm{z}$ błahych powodów.

Dokonując analizy małżeństwa jako społecznie nienaruszalnej instytucji, należy uprzednio poddać rozważeniu określenie samego 
terminu „małżeństwo”, ukazać czynniki, które podnoszą je do roli sacrum, oraz ukazać problemy małżonków, które lokują się w przestrzeni społeczno-moralnej. Skoro to, co łączy i wpływa na nienaruszalność tej instytucji, określamy jako sacrum, jednocześnie to, co dzieli i rozdziera małżeństwo, należy określić jako profanum. Profanacja tej świętej instytucji prowadzi do rozwodów. Dlatego też w drugiej części niniejszego artykułu zostanie poddany analizie rozwód, jego skala i przyczyny.

\section{Małżeństwo instytucją trwałą}

Małżeństwo w wymiarze ontologicznym jest wspólnotą trwałą. W niej jak w soczewce odzwierciedla się życie każdego człowieka i całego społeczeństwa. Dlatego też w każdej kulturze stanowi znak jedności kobiety i mężczyzny. Nie jest to jednak związek stricte prywatny, osobisty i indywidualny - ma także charakter publiczny, bowiem podlega prawom i zwyczajom danej społeczności. Dlatego instytucji tej przysługuje wysoka ranga w społeczeństwie. Ranga ta realizuje się w trwałości związku zawartego między kobietą a mężczyzną na całe życie, czyli aż do śmierci.

Dokonując analizy terminu „małżeństwo”, początkowo należy wyróżnić jego sens wąski i szeroki. W sensie wąskim jest to związek dwojga osób różnej płci. W sensie szerszym jest to związek mężczyzny i kobiety, na mocy którego posiadają pewne prawa, wyznaczane są im cele, zadania i funkcje. Bardzo trudno jest podać precyzyjną definicję tegoż pojęcia.

W literaturze przedmiotu można odnaleźć wiele definicji małżeństwa, różniących się w zależności od tego, kto definiuje ten termin: teolog, filozof, socjolog, pedagog, psycholog czy prawnik lub ekonomista. Niezależne od przyjętego kryterium naukowego małżeństwo zawsze sprowadza się do zespołu praw gwarantujących "prawość” 
pochodzenia dziecka i obdarowujących współmałżonków uprawnieniami seksualnymi².

Analizując małżeństwo jako instytucję trwałą, mamy na myśli jej formalne ustanowienie oraz funkcjonowanie według określonych norm i zasad społecznych. Stąd też sens małżeństwa jako instytucji sprowadza się w dużej mierze - a może nawet przede wszystkim - do pełnienia przez nie koniecznych dla społeczeństwa funkcji. Funkcja bowiem to określone działanie ukierunkowane na konkretny cel, kontynuowane w ramach całej struktury społecznej albo też dla podtrzymania danej społeczności.

Małżeństwo zawsze pozostanie instytucją, chociażby z samego faktu pełnienia przez małżonków trzech podstawowych funkcji: prokreacji, socjalizacji i miłości. Funkcje te wyznaczają właściwy zakres działań podejmowanych przez małżonków. Instytucja ta w sensie społecznym powinna więc zawsze być nierozerwalna.

Trwałość oznacza zawarcie małżeństwa na całe życie i tym samym instytucja ta jest związkiem dozgonnym. Trwałość małżeństwa wynika z samego faktu jego zawarcia i słów wypowiadanych przez nupturientów: „I ślubuję ci miłość, wierność i uczciwość małżeńską oraz ze cię nie opuszczę aż do śmierci”. Wypowiadane słowa uświadamiają małżonkom, jak dalece ważny jest ich związek. Związek, który nigdy nie przemija, bowiem zawierany jest wobec samego Boga. Za jego pośrednictwem zawierają oni przymierze z Bogiem, który w zamian za właściwe życie obiecuje im błogosławieństwo.

\section{Małżeństwo - to, co łączy}

Wielki myśliciel i uczony starożytności Arystoteles zauważył, że rodzina jako podstawowa komórka społeczna potrzebuje wielorakich, 
bogatych treściowo i trwałych kontaktów z innymi osobami i strukturami $^{3}$. Dlatego rodzinę interpretuje się jako instytucję tworzoną przez właściwe i tylko im znane relacje pomiędzy mężczyzną a kobietą. Relacje te są rodzajem więzi międzyosobowych, a dokładniej: więzi rodzinnych i małżeńskich.

Małżeństwo mężczyzny i kobiety zawiera się w harmonii życia opartego na miłości i zgodzie. Ze wszech miar małżonkowie winni dążyć do tego, aby umacniać więź małżeńską. Więź małżeńska to podstawowy element, którego celem jest scalanie małżonków, podejmowanie przez nich wspólnych zadań i dążenie do wspólnych celów, tworzenie harmonii życia i wspólnego bytowania w ognisku rodzinnym. Dzięki niej małżonkowie obdarowują się sobą i uzupełniają w podejmowanych przez siebie działaniach.

Pierwszymi i podstawowymi elementami warunkującymi właściwe postępowanie małżonków są te, które ich łączą. Łączy ich przede wszystkim wiara i miłość, rozumiana jako dar udzielony im przez samego Boga. Może być rozumiana też jako wartość ukierunkowana na współmałżonka.

Związek mężczyzny i kobiety jako jedność zapoczątkowana w sposób sakramentalny winna dążyć do świętości. Jest to podstawowy aspekt powołania małżeńskiego ${ }^{4}$. Świętość małżeńska - jak całe życie małżonków - musi być na wskroś ludzka, a więc łączyć w jedno ducha i ciało, i wypowiadać się zarówno w ciele, jak i w tym, co duchowe. Zgodnie z zamysłem Stwórcy rodzina została wezwana do świętości. Bóg wzywa małżonków do wypełnienia przez nich podstawowych zobowiązań: miłości, wierności i uczciwości ${ }^{5}$. Wprawdzie wiara jest wewnętrzną sprawą każdego człowieka, ale w rodzinie jest drogą wzajemnego uświęcania się, dążenia do świętości. Włączenie się zatem

3 Por. L. Dyczewski, Rodzina, społeczeństwo, państwo, Lublin 1994, s. 11-12.

4 Por. Jan Paweł II, O nierozerwalności matżeństwa, Kraków 2002, s. 30-31.

5 Por. M. Kluz, Miłość, wierność i uczciwość trwała podstawa życia małżeńskiego, „Studia Leopoliensia" 7 (2014), s. 111-125. 
małżonków w dzieło Stwórcy jest jednym z pierwszych blasków rodziny, który sytuuje ją w wymiarze ponadczasowym, w istocie zbawczym.

Fundamentem rodziny jest chrześcijańska miłość realizująca się jako osobowa więź małżonków. Ona prowadzi do poznawczo-wolitywnego aktu, czyli świadomego dążenia woli człowieka, do wspólnotowego i osobowego szczęścia, nadającego rodzinie i małżeństwu trwałość. Szczęście człowieka realizuje się szczególnie w rodzinie, która jest podmiotem jego integralnego, ontologicznego i epistemologicznego bytowania. Stąd chrześcijańska miłość odgrywa fundamentalną rolę wśród wszelkich wspólnot, bowiem stanowi rzeczywisty, moralnie wartościowy przejaw altruizmu, afirmacji siebie względem drugiej osoby, względem relacji rodzicielskich i relacji małżeńskich. Milość oznacza, że człowiek kocha i chce być kochanym. Nie ma małżeństwa bez miłości. Małżeństwo, w którym miłość się nie rozwija, wcześniej czy później umiera ${ }^{6}$.

Małżeństwo od samego początku swojego zaistnienia jest wspólnotą życia. Wspólnota ta realizuje się przez wspólne zamieszkanie: najpierw rodziców - małżonków, a potem i ich dzieci. Z samej swojej natury małżeństwo oraz miłość małżeńska nastawione są na rodzenie i wychowanie, co stanowi uwieńczenie wspólnoty życia. Dlatego tez ważnym problemem współczesnej cywilizacji jest nie tyle znalezienie wspólnego fundamentu wartości, na których buduje się wspólnotę rodziny, ile przede wszystkim realizowanie wartości, dzięki którym rodzina osiąga optymalny wymiar społecznego i ludzkiego rozwoju.

Podstawowym zadaniem małżonków jest słu ż b a ży ci u, czyli podejmowanie wszelkich starań na rzecz zaspokajania najważniejszych ich potrzeb. Termin „służba życiu” można definiować w dwojaki sposób. Pierwszy odnosi się do autorytetu rodziców względem dzieci, zaś drugi dotyczy samej osoby, która jest uczestnikiem służby,

6 Por. A. Sarmiento, Małżeństwo chrześcijańskie. Podręcznik teologii małżeństwa i rodziny, przeł. P. Rak, Kraków 2002, s. 48-55. 
podporządkowując się innej osobie. Służba ta w nieodłączny sposób

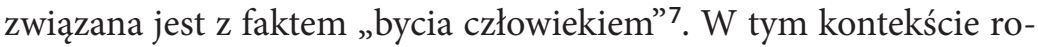
dzice są strażnikami życia, nie tylko mu służą, lecz także go bronią. „Trzeba zatem - podkreśla Jan Paweł II w Centesimus annus - odkryć na nowo, że rodzina jest $\mathrm{s}$ a $\mathrm{n} \mathrm{kt} u$ a r i u $\mathrm{m} \dot{\mathrm{z}} \mathrm{yc}$ i a. Istotnie bowiem jest ona święta: jest miejscem, w którym życie, dar Boga, może w sposób właściwy być przyjęte i chronione przed licznymi atakami, na które jest ono wystawione, może też rozwijać się zgodnie z wymogami prawdziwego ludzkiego wzrostu. Wbrew tak zwanej kulturze śmierci, rodzina stanowi ośrodek kultury życia" ${ }^{8}$. Wprawdzie obrona życia jest zadaniem wszystkich ludzi, ale rodzice znajdują się na jego początku, kiedy jest ono najbardziej bezbronne. Służba życiu oznacza zatem nie tylko uczestniczenie w prokreacji i otwarcie się na życie, lecz także kształtowanie tego życia.

Prokreacj a jest darem udzielonym małżonkom, którzy w odpowiedzialny sposób odpowiadają na wezwanie Boga: „Bądźcie płodni i rozmaczajcie się, abyście zaludnili ziemię i uczynili ja sobie poddaną” (Rdz 1, 28). „Przekazywanie życia - jak uczy Benedykt XVI - wpisane jest w naturę, a jej prawa są niczym niepisana norma, którą wszyscy powinni się kierować. Wszelkie próby odwodzenia od tej zasady są jałowe i nie mają przyszłości" ${ }^{9}$.

Od początku istnienia nowy człowiek - dziecko - jest darem nie tylko dla samych rodziców, lecz także całego społeczeństwa. Prokreacja bowiem to dar, jaki otrzymali małżonkowie, zobowiązujący ich do realizacji nie tylko siebie, lecz także nade wszytko planu Bożego. Przez prokreację Bóg pozwala im uczestniczyć w tajemnicy

7 Por. J. Orchowski, Prawo do życia nienarodzonych, "Chrześcijanin w Świecie" 19 (1987) nr 11, s. 39-37.

8 Jan Paweł II, Encyklika Centesimus annus, 39.

9 Benedykt XVI, Encyklika, która stała się znakiem sprzeciwu. Przemówienie do uczestników kongresu z okazji 40-lecia Encykliki Pawła VI "Humanae vitae" (Watykan, 10 maja 2008), "L'Osservatore Romano” 29 (2008) nr 6, wyd. pol., s. 40. 
życia i czyni z nich orędowników światła wiary. Tym bardziej że płodność miłości małżeńskiej nie ogranicza się jedynie do fizycznego rodzenia dzieci, ale poszerza się i ubogaca wszelkimi owocami życia moralnego, duchowego i nadprzyrodzonego ${ }^{10}$.

Rodzina realizuje się nie tylko przez dawanie życia, lecz także przez pielęgnację i ochronę tego życia. Dzieci od samego początku są poddawane procesowi wychowania. Właściwe wychowanie powinno obejmować wszystkie dziedziny życia ludzkiego: biologiczną, emocjonalną, psychiczną, społeczną, religijną i moralną ${ }^{11}$. Dlatego też rodzinę nazywa się szkołą bogatszego człowieczeństwa. Prawdziwe wychowanie domaga się humanizmu, albowiem jego brak powoduje nasilenie się zła i fałszu. Rodzice są nie tylko wychowawcami w pierwszym stadium życia człowieka, lecz do końca jego życia pozostają także niezastąpionymi przewodnikami kształtowania się aksjologii cnót w sercu człowieka. Tylko wychowanie do właściwego ukształtowania systemu wartości pozwoli dzieciom zrozumieć siebie, zrozumieć świat i kształtować go na wzór Boga Stwórcy ${ }^{12}$.

\section{Małżeństwo - to, co może dzielić (trudności małżeńsko-rodzinne)}

Chociaż małżeństwo powinno być instytucją trwałą, współcześnie coraz częściej zauważa się, że często nie tylko ulega ono dehumanizacji,

10 Por. Jan Paweł II, Adhortacja apostolska Familiaris consortio o zadaniach rodziny chrześcijańskiej w świecie współczesnym, 28.

11 Podobnie stwierdza Kodeks prawa kanonicznego (kan. 1136): „Rodzice mają najcięższy obowiązek i najpierwsze prawo troszczenia się zgodnie, według swoich możliwości, o wychowanie potomstwa zarówno fizyczne, społeczne i kulturalne, jak i moralne oraz religijne".

12 Por. Benedykt XVI, Rodzina chrześcijańska wspólnota wychowania i wiary. Przemówienie do uczestników Kongresu Diecezji Rzymskiej (Watykan, 6 maja 2005), "L'Osservatore Romano" 26 (2005) nr 9, wyd. pol., s. 33. 
lecz także napotyka wiele problemów i kryzysów, z którymi sobie nie radzi. Kryzys y w małżeństwie i w rodzinie łączą się z brakiem poczucia więzi - to ich pierwsza przyczyna. Kryzysy mogą posiadać różną naturę. Ich powszechność i nieuchronność jest konsekwencją współegzystencji osób różniących się od siebie temperamentem, charakterem. Sprzyjają im liczne, czasem nawet niezależne od samych małżonków lub nieprzewidziane sytuacje. Często się zdarza, że małżonkowie żyjący w ciągłym pośpiechu, pochłonięci własnymi sprawami wykazują tendencje do oceniania męża czy żony na podstawie zachowań. Rzadko kiedy zdobywają się na to, by dociec, jakie są przyczyny czyjegoś postępowania oraz jakie są rzeczywiste źródła konfliktów i przeżywanych napięć ${ }^{13}$.

Analizując czynniki warunkujące pojawianie sie kryzysów małżeńskich, należny uwzględnić: brak komunikacji małżeńskiej, brak wierności, egoizm, brak dojrzałości i zaburzenia emocjonalne małżonków (zob. schemat 1).

Psychiki kobiety i mężczyzny różnią się znacznie, stąd w każdym związku dochodzi do nieporozumień, konfliktów, zadrażnień. Właściwa komunikacja jest jedynym sposobem, aby utrzymać związek, zażyłość, uczucie pomiędzy dwiema osobami różniącymi się nieraz praktycznie wszystkim: nie tylko płcią, lecz także wykształceniem, pochodzeniem, mentalnością, marzeniami. Brak komunikacji w małżeństwie prowadzi do dysharmonii. Wówczas pojawiają się sytuacje, z którymi małżonkowie sobie nie radzą, a ich rozmowy stają się coraz bardziej konfliktowe. Nie stać ich już na kompromis, ustępstwo, a różnica zdań prowadzi do kłótni, wobec której nie sposób już być obojętnym.

13 Por. A. Moir, D. Jessel, Płeć mózgu. O prawdziwej różnicy między mężczyznq a kobieta, przeł. Nina Kancewicz-Hoffman, Warszawa 1995, s. 178. Por. także M. Kluz, Sztuczne zapłodnienie a chrześcijańska wizja małżeństwa i rodziny, w: Małżeństwo i rodzina wciqż fundamentem nowej cywilizacji. Refleksje na kanwie dokumentu Konferencji Episkopatu Polski pt. "Służyć prawdzie o małżeństwie i rodzinie”, red. R. Kantor, M. Kluz, Tarnów 2011, s. 43-46. 
Schemat 1. Małżeństwo - to, co dzieli

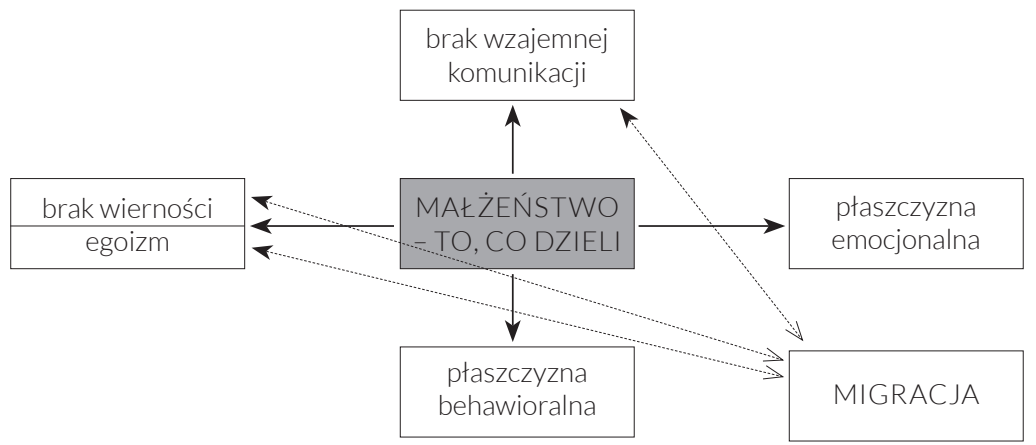

Źródło: opracowanie własne.

Konflikty mogą być różne - ich przyczyną mogą stać się sprawy najbardziej błahe, prozaiczne sytuacje, czasem dotyczących wychowania dziecka, a czasem zwykłych codziennych zachowań. Oczywiście mogą one wynikać także $\mathrm{z}$ różnicy charakterów małżonków albo z problemów, jakie jedno z nich przeżywa w pracy. Konflikty od zawsze były czymś złym w kontekście relacji interpersonalnych - dzieliły i nigdy nie umacniały więzi.

Kolejną przyczyną poróżnień w małżeństwie jest e g o i z m. Należy uznać, iż wszelkie jego formy stoją w sprzeczności z życiem małżeńsko-rodzinnym i dlatego pozostają wielkim zagrożeniem dla każdego związku. Małżeństwo, jak wiadomo, jest wspólnotą życia i miłości. Stąd też każdy przejaw egoizmu ze strony któregokolwiek z małżonków prowadzi do jego destrukcji - tym bardziej że we właściwie pojmowanym małżeństwie cele jednostkowe są zawsze celami całej rodziny, natomiast cele rodziny są celami każdego jej członka ${ }^{14}$.

14 Por. W. Majkowski, Zagrożenia współczesnej rodziny, w: Rodzina polska u progu trzeciego tysiq̨clecia. Materiały z sympozjum zorganizowanego przez Instytut Socjologii UKSW w dniach 17-18 listopada 2001 roku, red. W. Majkowski, Warszawa 2003, S. 29. 
Egoistyczne postawy niszczą małżeństwo w jego strukturze wewnętrznej, powodując wielkie cierpienia. Egoizm jest bowiem zaprzeczeniem postawy miłości. Może być on jednak wybierany świadomie. Skłania do tego np. ideologia skrajnego indywidualizmu (hiperindywidualizmu). Wmawia ona człowiekowi, że skoro jest on „najwyższą wartością", to jest też najwyższym dobrem. Ma zatem prawo wszystko i wszystkich sobie podporządkować, wszystko mu się należy - bez względu na ważność powodu, nawet gdy to zwykły kaprys. Paradoksem jest, że ludzie o postawie egoistycznej żądają prawa do miłości, która im się oczywiście - jak wszystko - za darmo należy. Nie widzą wewnętrznej sprzeczności między swoją postawą a postawą miłości - tymczasem tam gdzie jest prawdziwa miłość, nie ma zazdrości i nie ma egoizmu ${ }^{15}$.

Kolejną ważną płaszczyzną życia małżeńskiego, która staje się przyczyną konfliktów, jest kwestia wierności małżeńskiej. Za każdą zdradę trzeba zapłacić, a dość często kończy się zniszczeniem miłości małżeńskiej. Istnieje duże prawdopodobieństwo, że któryś z małżonków hedonistycznie nastawiony do życia wcześniej czy później skorzysta z nadarzającej się okazji i wejdzie w sferę pozamałżeńskich kontaktów seksualnych. Jest to niejako zgodne $\mathrm{z}$ jego chęcią pogoni za przyjemnością Zagrożenie dla małżeństwa, jakim jest implikowana postawą hedonistyczną zdrada, to czyn ze wszech miar niegodziwy, bezpośrednio niszczący piękno życia małżeńskiego ${ }^{16}$.

Każda zdrada rodzi poważny konflikt w życiu małżeńsko-rodzinnym. Nie tylko nie leczy kryzysu małżeńskiego, ale jeszcze go zwielokrotnia. Zdrada niszczy, a przekonanie, że romans może

15 W. Majkowski, Rodzina polska w kontekście nowoczesnych uwarunkowań, Kraków 2010, s. 264-266.

16 Por. J. Salij, Wierność jako fundament małżeństwa. Obrona trwałości i nierozerwalności małżeństwa wobec postmodernistycznego kultu płynności, „Teologia i Moralność" 4 (2008), s. 52-55. Por. także I. Mroczkowski, Ślubuję ci wierność, w: Miłość, wierność i uczciwość małżeńska. Przesłanie moralne Kościoła, red. K. Jeżyna, T. Zadykowicz, Lublin 2006, s. 17-19. 
uratować życie małżeńskie, jest wielce nieracjonalne. Każdy związek powinien być oparty na miłości, która go cementuje, daje poczucie wspólnoty. Niestety nie zawsze tak jest. Małżeńska niewierność nie tylko wprowadza dysharmonię w życie małżeńsko-rodzinne, lecz także w jakiejś mierze zamyka małżonków na dalsze zgodne życie, bez względu na to, czy sami podejmą jakieś działania w kierunku życia razem lub w pojedynkę ${ }^{17}$.

Źródłem dysharmonii w rodzinie mogą też być problemy małżonków ze sfer ą e mo cj on al ną. Mylenie miłości z pożądaniem jest niebezpieczne. Ileż małżeństw zostało zawartych wyłącznie siłą rozpędu uczuć wywołanych najczęściej bliskością cielesną. Małżeństwa zbudowane na błędnie pojmowanej emocjonalności nie przetrwają długo, bowiem zabraknie w nich tego wszystkiego, co stwarza prawdziwa miłość. Dojrzałość emocjonalna jest kluczowym warunkiem scalającym małżeństwo i rodzinę. Bez umiejętności kreowania trwałych i głębokich więzi uczuciowych stworzenie dobrej atmosfery w rodzinie wydaje się niemożliwe. Zaprzeczeniem takiej dojrzałej postawy są zachowania neurotyczne mające swoje podłoże także na płaszczyźnie behawioralnej.

Ostatnim obszarem, który w pewnej mierze również może dzielić małżonków, jest migracja zarobkowa ${ }^{18}$. Z jednej strony przynosi wiele niezaprzeczalnie pozytywnych skutków, szczególnie na płaszczyźnie ekonomicznej, ale z drugiej bardzo często prowadzi do de-

17 W. Majkowski, Czynniki dezintegracji współczesnej rodziny polskiej. Studium socjologiczne, Kraków 1997, s. 132.

18 J. Młyński, W. Szewczyk, Migracje zarobkowe Polaków. Badania i refleksje, Tarnów 2010; J. Młyński, Migracja zarobkowa w kontekście zmieniajacej się rzeczywistości. Korzyści i zagrożenia, „Pedagogika Katolicka” 2010 nr 6, s. 197-214; J. Młyński, W. Szewczyk, Rodzina wobec dylematów migracji zarobkowej. Badania i analizy, Warszawa 2012; J. Młyński, W. Szewczyk, Rodzina a migracja. Materiały z międzynarodowej konferencji naukowej zorganizowanej przez Wydział Nauk nad Rodzinq UKSW w Warszawie, Kraków 2012; J. Młyński, Migracje rodziców jako zjawisko społeczno-wychowawcze w kontekście uwarunkowań pedagogiki dzieci, "Roczniki Nauk o Rodzinie i Pracy Socjalnej" 2012 nr 4, s. 67-92. 
strukcji w małżeństwie i rodzinie. Z badań wynika, że tych drugich, niepożądanych skutków jest o wiele więcej. Truizmem jest stwierdzenie, że do właściwego funkcjonowania małżeństwa, tworzenia i utrzymywania więzi, konieczna jest bliskość, także ta fizyczna. Jak się wydaje, migracja zakłóca istotę bliskości ${ }^{19}$.

Migracja zarobkowa szczególnie niekorzystnie wpływa na małżonków na dwóch płaszczyznach: emocjonalnej i behawioralnej. $\mathrm{Na}$ płaszczyźnie emocjonalnej wzmagają się uczucia takie jak tęsknota i osamotnienie. Powodują one zachwianie poczucia bezpieczeństwa w rodzinie, a w konsekwencji prowadzą do destrukcji więzi małżeńskiej, szczególnie wówczas, gdy w wyniku rozłąki rodzą się uczucia złości do współmałżonka, niechęć do niego, oziębłość emocjonalna. Jednocześnie może także osłabnąć fascynacja współmałżonkiem i czułość do niego. Na płaszczyźnie behawioralnej rozłąka powoduje zmiany w ogólnym zachowaniu małżonków. Przede wszystkim następuje zanik komunikacji „twarzą w twarz”. Dominującym sposobem rozmowy staje się kontakt za pośrednictwem telefonu lub internetu. Tymczasem wiadomo, iż kontakt bezpośredni daje więcej możliwości okazywania sobie uczuć, a także komunikowania się niewerbalnie. Wiele rzeczy, które trudno jest wypowiedzieć, można zauważyć w sposobie postępowania i zachowania danej osoby. Wreszcie ważna wydaje się częstotliwość rozmów między małżonkami. Przebywając ze sobą codziennie, rozmawiają oni bardzo często, zaś podczas rozłąki migracyjnej te rozmowy są coraz rzadsze ${ }^{20}$.

19 Por. K. Wojaczek, Rodzina w konfrontacji z migracja zarobkowq, w: Wyjazdy zarobkowe - szansa czy zagrożenie? Perspektywa społeczno-moralna, red. K. Glombik, P. Morciniec, Opole 2005, s. 214-217. Por. także: M. Kluz, Moralna ocena zjawiska migracji zarobkowej, w: Rodzina a migracja..., dz. cyt., s. 135-143.

20 Por. D. Gizicka, J. Gorbaniuk, M. Szyszka, Rodzina w sytuacji rozłąki migracyjnej, Lublin 2010, s. 19-24; K. Wojaczek, Więź małżeńska w sytuacji rozłąki z przyczyn ekonomicznych. Studium pastoralne, Opole 2007, s. 81nn (Człowiek, Rodzina, Społeczeństwo, 9). 
Przywołane powyżej i przedstawione na schemacie 1 czynniki dzielące współczesną rodzinę uświadamiają, że zarówno ona, jak i małżeństwo ulegają dezintegracji, dlatego potrzebują pomocy instytucjonalnej i indywidualnej. Jednak przede wszystkim każdy człowiek podejmujący decyzję o małżeństwie winien uprzednio postawić sobie pytanie, dlaczego chce zawrzeć związek małżeński, do czego się zobowiązuje i czego oczekuje. Albowiem w przemyślanej decyzji i dojrzałości emocjonalnej tkwią sukces i szczęście każdego małżeństwa i rodziny.

\section{Rozwód - skala i przyczyny}

Osłabienie więzi małżeńsko-rodzinnej skutkuje dezintegracją małżeństwa, brakiem wzajemnej akceptacji, co znajduje swoje odbicie we wzrastającej liczbie rozwodów ${ }^{21}$. Przez rozwód rozumie się trwały i zupełny rozkład pożycia małżeńskiego. Następuje on w sferze emocjonalnej, psychicznej, fizycznej, ekonomicznej, co uniemożliwia kontynuowanie dalszego wspólnego życia.

W ujęciu socjologicznym rozwód oznacza dezintegrację grupy społecznej oraz jest wynikiem zmiany wzoru procesów prokreacji i socjalizacji. W każdym przypadku w pierwszym stadium rozwód jest faktem emocjonalnym, bowiem osłabiają, a nawet rozpadają się więzi uczuciowe współmałżonków. Jest on zjawiskiem niekorzystnym szczególnie w sferze moralności, gdyż rozejście się rodziców

21 "Ze zjawiskiem rozwodów jako faktem społeczno-prawnym mamy do czynienia w Polsce od początku lat pięćdziesiątych. Wiąże się ono z dokonaną w roku 1946 laicyzacją prawa małżeńskiego i zerwaniem przez władze komunistyczne konkordatu z roku 1925, mocą którego wprowadzona została instytucja separacji jak powiedziano wyżej - przywrócona ponownie w roku 1998 na podstawie nowego konkordatu, którego zawarcie było możliwe po polityczno-ustrojowych przemianach roku 1989". Por. F. Adamski, Rodzina. Wymiar społeczno-kulturowy, Kraków 2002, s. 188. 
źle wpływa na psychikę dzieci, dla których ten fakt jest wydarzeniem traumatycznym. Niektórzy naukowcy uważają, że w pewnych wypadkach rozwód jest lepszym rozwiązaniem, bowiem izoluje się w ten sposób dzieci od atmosfery ciągłego napięcia i konfliktów. Nic bardziej mylnego - każdy rozwód pozostawia skazę w sercu dziecka bez względu na wiek i stan wrażliwości.

Chociaż rozpad małżeństwa jest bardzo bolesnym doświadczeniem dla rozchodzących się małżonków, to liczba rozwodów się nie zmniejsza. Ze wstępnych danych wynika, że w 2007 roku w stosunku do 2006 roku liczba rozwodów wzrosła o blisko 6 tys., co oznacza, że w 2007 roku rozwodziło się prawie 72 tys. par. W 2008 roku na każde 100 tys. zawartych małżeństw 254 zostały rozwiązane na drodze sądowej. W miastach intensywność rozwodów jest prawie trzy razy wyższa niż na wsi ${ }^{22}$. Statystykę rozwodów w ostatnim dziesięcioleciu przedstawiają tabela 1 oraz wykres 1 .

Tabela 1. Rozwody w Polsce w latach 2001-2013

\begin{tabular}{|c|c|c|c|c|c|c|c|}
\hline \multirow{2}{*}{ Lata } & \multirow{2}{*}{$\begin{array}{c}\text { Liczba } \\
\text { rozwodów }\end{array}$} & \multicolumn{3}{|c|}{$\begin{array}{c}\text { Współczynniki rozwodów } \\
\text { na 10 tys. ludności }\end{array}$} & \multicolumn{2}{|c|}{$\begin{array}{c}\text { Współczynniki rozwodów } \\
\text { na 100 tys. nowo zawartych } \\
\text { małżeństw }\end{array}$} \\
\cline { 3 - 8 } & & ogółem & miasta & wieś & ogółem & miasta & wieś \\
\hline 2001 & 45308 & 11,7 & 16,1 & 4,7 & 232,2 & 323,2 & 91,5 \\
\hline 2002 & 45414 & 11,8 & 16,2 & 4,7 & 237,2 & 330,4 & 93,1 \\
\hline 2003 & 48632 & 12,7 & 17,4 & 5,2 & 248,8 & 344,3 & 99,9 \\
\hline 2004 & 56322 & 14,7 & 19,6 & 7,0 & 293,2 & 394,8 & 136,4 \\
\hline 2005 & 67578 & 17,7 & 23,0 & 9,3 & 326,6 & 426,7 & 170,3 \\
\hline 2006 & 71912 & 18,7 & 24,6 & 9,3 & 317,9 & 422,2 & 155,1 \\
\hline
\end{tabular}

22 Por. Główny Urząd Statystyczny, Departament Badań Demograficznych, Podstawowe informacje o rozwoju demograficznym Polski w latach 2000-2009, www.stat. gov.pl/cps/rde/xbcr/gus/lu_podsta_info_o_rozwoju_demograf_polski_2000-2009. pdf (1.03.2012). 


\begin{tabular}{|c|c|c|c|c|c|c|c|}
\hline \multirow{2}{*}{ Lata } & \multirow{2}{*}{$\begin{array}{c}\text { Liczba } \\
\text { rozwodów }\end{array}$} & \multicolumn{4}{|c|}{$\begin{array}{c}\text { Współczynniki rozwodów } \\
\text { na 10 tys. ludności }\end{array}$} & \multicolumn{2}{|c|}{$\begin{array}{c}\text { Współczynniki rozwodów } \\
\text { na 100 tys. nowo zawartych } \\
\text { matżeństw }\end{array}$} \\
\cline { 3 - 8 } & & ogółem & miasta & wieś & ogółem & miasta & wieś \\
\hline 2007 & 66586 & 17,5 & 22,6 & 8,7 & 277,7 & 354,3 & 131,6 \\
\hline 2008 & 65475 & 17,2 & 22,4 & 8,8 & 254,0 & 335,3 & 127,0 \\
\hline 2009 & 65345 & 17,1 & 22,2 & 9,0 & 260,6 & 336,7 & 137,1 \\
\hline 2010 & 61300 & 16,1 & 20,4 & 9,0 & 268,5 & 345,4 & 147,3 \\
\hline 2011 & 64594 & 21,3 & 26,1 & 13,0 & 313,0 & 401,0 & 177,1 \\
\hline 2012 & 64432 & 16,7 & 20,8 & 10,1 & 316,1 & 406,6 & 181,6 \\
\hline 2013 & 66132 & 17,2 & 21,2 & 10,6 & 366,6 & 466,7 & 216,0 \\
\hline
\end{tabular}

Źródło: opracowanie własne na podstawie danych GUS: Sytuacja demograficzna Polski, w: Raport 2001-2012, Warszawa 2012, s. 80, oraz „Rocznik Demograficzny” 2013.

Wykres 1. Dynamika rozwodów w Polsce

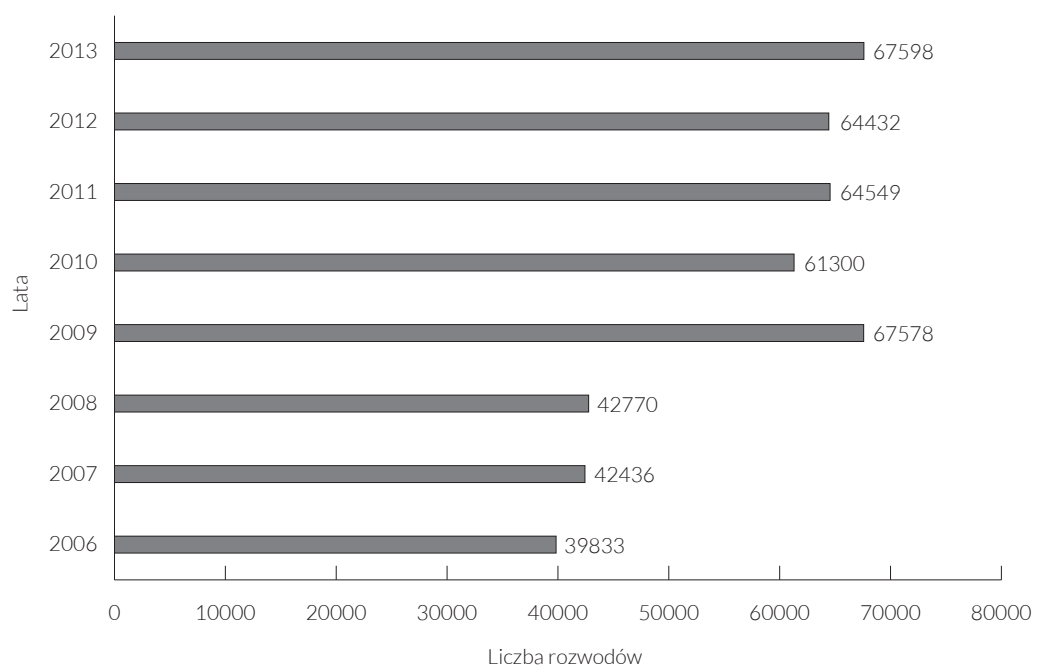

Źródło: opracowanie własne na podstawie danych GUS: „Rocznik Demograficzny” 1982, 2000, 2014, „Rocznik Statystyczny” 1982, 2000, 2014. 
Wykres 2. Liczba rozwodów w niektórych państwach

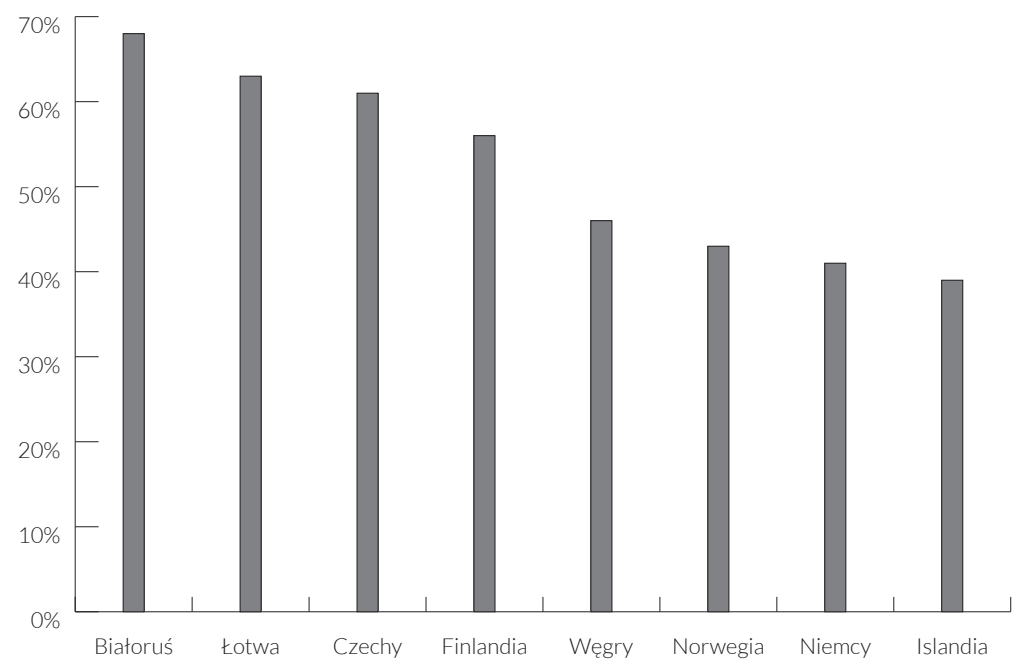

Źródło: www.divorce.com/article/worldwide-divorce-statistics (dane na dzień 12.05.2012).

W państwach wysoko rozwiniętych współczynnik rozwodów jest bardzo wysoki. Kraje europejskie, w których rozpada się co drugie zawarte małżeństwo, to Austria, Belgia, Białoruś, Czechy, Estonia, Finlandia, Hiszpania, Litwa, Łotwa, Norwegia, Rosja, Szwecja, Szwajcaria i Ukraina. W wypadku Białorusi nieskomplikowana kalkulacja wskazuje na niepokojący trend. Na przełomie stycznia i lutego $2009 \mathrm{r}$. na 1000 zawartych małżeństw przypadło 469,3 rozwodów, zaś w roku 2010 w tym samym okresie $572,7^{23}$.

Dokonując analizy przyczyn rozwodów, należałoby najpierw zwrócić uwagę na fakt, iż współcześnie rozwód nie jest tematem tabu. Jak niegdyś łączył się niejako z wykluczeniem człowieka ze

23 Por. BGD, Białoruś: Ludności mniej, rozwodów więcej, nowa.bialorus.pl/spoleczenstwo?artid=434 (1.03.2014). 
Wykres 3. Przyczyny rozwodów w Polsce

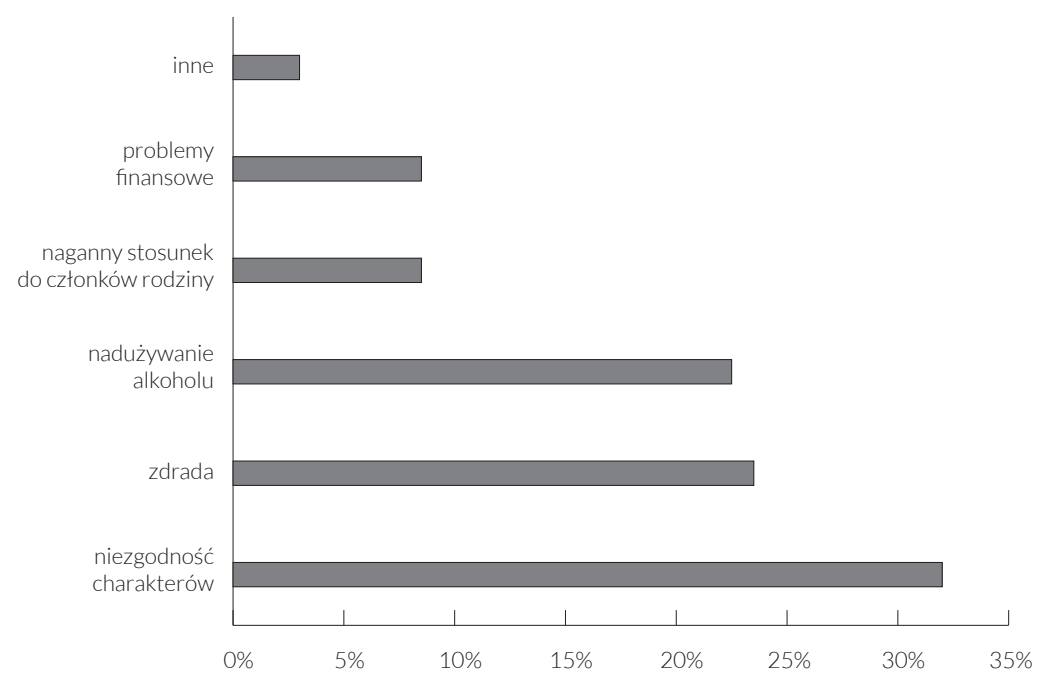

Źródło: opracowanie własne na podstawie GUS.

społeczności i traktowaniem go w sposób drugorzędny, tak dzisiaj zyskuje przyzwolenie w opinii społecznej. Dlatego też w literaturze przedmiotu, gdy dokonuje się analizy rozwodów, najpierw poszukuje się ogólnych przyczyn prowadzących do rozpadu małżeństwa. Wśród przyczyn najczęściej wymienia się aspekty pozytywne i negatywne. Do tych pierwszych zalicza się: łatwość, z jaką można otrzymać rozwód, dobre warunki ekonomiczne, większa społeczna akceptowalność rozwodów, chęć przeżycia nowej, romantycznej miłości.

Jeszcze do niedawna pierwszą przyczyną rozpadu rodziny była śmierć jednego ze współmałżonków - obecnie coraz częściej decydują o nim rozwód i separacja. Socjologowie, dokonując analizy rozwodów, wskazują najczęstsze ich przyczyny: niezgodność charakterów, zdradę, nadużywanie alkoholu, naganny stosunek do członków 
rodziny oraz problemy finansowe. W ujęciu procentowym przedstawia je wykres 3.

Jeszcze inną ważną przyczyną rozwodów, chociaż nie bezpośrednią, jest wspomniana wcześniej migracja zarobkowa. Zjawisko migracji, choć często opisywane, nie zostało jeszcze do końca przebadane w tym kontekście. Jednak mimo braku jednoznacznych badań już dzisiaj można postawić hipotezę, że istnieje związek przyczynowy pomiędzy wzrostem rozpadu małżeństw a intensyfikacją migracji zarobkowych. Potwierdzają to dane przedstawione w tabeli 2.

Tabela 2. Ludność i migracje w latach 1960-2013

\begin{tabular}{|c|c|c|c|c|}
\hline \multirow{2}{*}{ Lata } & \multirow{2}{*}{$\begin{array}{c}\text { Liczba zawartych } \\
\text { małżeństw (tys.) }\end{array}$} & \multirow{2}{*}{$\begin{array}{c}\text { Liczba orzeczonych } \\
\text { rozwodów (tys.) }\end{array}$} & \multicolumn{2}{|c|}{ Liczba migrujących (tys.) } \\
\cline { 4 - 5 } & 244,2 & 14,8 & 5,7 & 28,0 \\
\hline 1960 & 280,3 & 34,6 & 1,9 & 14,1 \\
\hline 1970 & 307,4 & 39,8 & 1,5 & 22,7 \\
\hline 1980 & 255,4 & 42,4 & 2,6 & 18,4 \\
\hline 1990 & 211,2 & 42,8 & 7,3 & 27,0 \\
\hline 2000 & 191,9 & 45,4 & 6,6 & 24,5 \\
\hline 2002 & 195,4 & 48,6 & 7,0 & 20,8 \\
\hline 2003 & 191,8 & 56,3 & 9,5 & 18,9 \\
\hline 2004 & 206,9 & 67,6 & 9,3 & 22,2 \\
\hline 2005 & 257,7 & 65,5 & 15,3 & 30,1 \\
\hline 2008 & 250,8 & 65,3 & 17,4 & 18,6 \\
\hline 2009 & 228,4 & 61,3 & 15,2 & 17,3 \\
\hline 2010 & 203,8 & 64,4 & 14,5 & 21,2 \\
\hline 2012 & 180,4 & 66,2 & 12,1 & 32,1 \\
\hline 2013 & & & & \\
\hline
\end{tabular}

Źródło: dane GUS, Ruch naturalny i migracje ludności, „Rocznik Demograficzny” 2014, s. 40. 


\section{Podsumowanie}

Rodzina (i małżeństwo jako jej podstawa) stanowi naturalną grupę społeczną, w której człowiek się rodzi, wychowuje i staje się w pełni ukształtowaną jednostką. Ma ona utrzymywać ciągłość biologiczną społeczności ludzkiej oraz przekazywać dziedzictwo kulturowe. Tylko dobrze funkcjonująca rodzina może właściwie rozwijać i przekazywać wartość, jaką jest miłość.

Miłość małżeńska obejmuje całą osobę współmałżonka, rodzi pragnienie wspólnego życia na zawsze. W kochających się dwojgu ludzi budzi się i rozwija poczucie odpowiedzialności za przyszłość każdego z nich. Wyraża się ono w życzliwości, w zaufaniu, poszanowaniu wzajemnej godności, wymianie myśli, dobroci. Szczęśliwe i harmonijne życie małżonków powinno prowadzić ich do wzajemnego szacunku, by z miłości uczynić wartość bycia darem dla drugiej osoby. Niestety czasem jest inaczej. Afirmacja związku przeradza się w jego negację. Wówczas dochodzi w małżeństwie do problemów, konfliktów, a nawet kryzysów. Pierwszym przejawem kryzysu trwałości małżeństwa jest egoizm. Może się on przejawiać w codziennym życiu albo w szukaniu kontaktów z osobą trzecią. Nieopanowany egoizm jest źródłem wielu cierpień, zaburzeń, wypaczeń w życiu rodzinnym. Może zburzyć harmonię i szczęście małżeńskie.

Świadomość trwałości związku małżeńskiego i jego nierozerwalności pozwala przezwyciężać początkowe trudności, a nawet opanować dochodzący do głosu egoizm. Uzmysłowienie sobie tego faktu jest szkołą życia małżeńskiego odpowiadającego godności ludzkiej. Trwałości małżeństwa służy dobru małżonków. Jeśli jednak małżonkowie pogubili się na drodze do jedności, wówczas przez brak odpowiedzialności i właściwej postawy dochodzi do agonii miłości. Pierwsza zawsze umiera miłość. Gdy umiera miłość, umiera zaś małżeństwo. Gdy umiera jedność małżonków, dochodzi do rozwodu.

Rozwód jako niepokojące zjawisko współczesności ma wiele konsekwencji. Przede wszystkim najbardziej poszkodowane są dzieci, 
które zawsze traumatycznie przeżywają rozejście się rodziców i nikt nie jest wstanie zabliźnić ran, jakie powstały w ich psychice. Załamuje się i popada w ruinę cały ich dotychczasowy świat, poczucie bezpieczeństwa oraz system wartości. Również sami małżonkowie, oddaleni od siebie, stają się skłonni do agresji, rodzi się w nich poczucie odrzucenia, osamotnienia i krzywdy.

W społeczeństwie istnieją dwa zjawiska, które wpływają na rozpad małżeństwa: społeczna akceptacja rozwodu oraz zawieranie małżeństw pod presją tradycyjnego wzorca. Rozluźnienie obyczajów, zanik wartości oraz osłabienie autorytetu Kościoła wydają się wpływać na nietrwałość małżeństwa.

Co robić, aby zmniejszyć rosnącą liczbę rozwodów? Na to pytanie trudno udzielić jednoznacznej odpowiedzi. Niemniej należałoby przede wszystkim wzmagać poczucie odpowiedzialności, że małżeństwo jest najwyższą wartością i każde złamanie przysięgi małżeńskiej jest nie tylko zdradą, lecz także moralnie niegodziwym aktem wobec Boga i człowieka. Może warto byłoby powrócić do punktu 6 Deklaracji w sprawie polityki rodzinnej przyjętej przez rząd i episkopat Polski 19 listopada 2008 roku. Mówi się w niej o pilnej potrzebie przeciwdziałanie kryzysom i rozpadowi rodzin. Uznano za niezbędne wsparcie małżeństwa przez rozwój poradnictwa rodzinnego i przygotowanie młodzieży do założenia rodziny. Jako ważne zadanie wskazano poprawienie prawa rodzinnego, m.in. przez zwiększenie roli mediacji pomiędzy małżonkami, co miałoby przyczynić się do rozwiązywania problemów w małżeństwie. Wreszcie państwo powinno proponować rozwiązania sprzyjające trwałości małżeństw, a nie ich rozpadom. Należałoby zatem zastanowić się nad polityką rodzinną. Małżeństwo bowiem jest darem Boga i spełnieniem człowieka, a każdy dar należy chronić ${ }^{24}$.

24 Por. T. Michalik, Rozwody wyzwaniem katechetycznym, w: Małżeństwo i rodzina wciąż fundamentem nowej cywilizacji..., dz. cyt., s. 85-94. 
- 